\title{
Emissions Results for Dedicated Propane Chrysler Minivans: The 1996 Propane Vehicle Challenge
}

\author{
Carlos Buitrago, Scott Sluder, and Robert Larsen \\ ANL/ES/CP-92071
CONF-970210--3 \\ Center for Transportation Research \\ Argonne National Laboratory

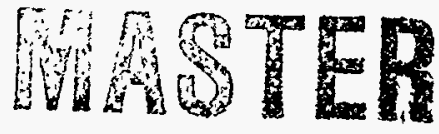 \\ The submitted manuscript has been authored \\ by a contractor of the U.S. Government \\ under contract No. W-31-109-ENG-38. \\ Accordingly, the U.S. Government retains a \\ nonexclusive, royalty.free license to publish \\ or reproduce the published form of this \\ contribution, or allow others to do so, for \\ U.S. Government purposes.
}

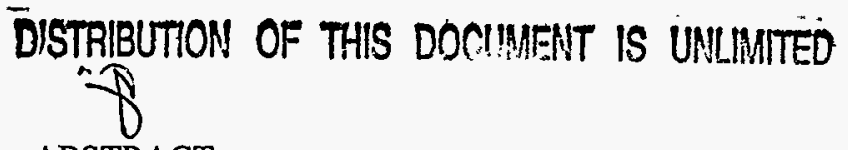

ABSTRACT

The U.S. Department of Energy, through Argonne National Laboratory, and in cooperation with Natural Resources-Canada and Chrysler Canada, sponsored and organized the 1996 Propane Vehicle Challenge (PVC). For this competition, 13 university teams from North America each received a stock Chrysler minivan to be converted to dedicated propane operation while maintaining maximum production feasibility. The converted vehicles were tested for performance (driveability, cold- and hot-start, acceleration, range, and fuel economy) and exhaust emissions. Of the 13 entries for the 1996 PVC, 10 completed all of the events scheduled, including the emissions test. The schools used a variety of fuel-management, fuel-phase and engine-control strategies, but their strategies can be summarized as three main types: liquid fuel-injection, gaseous fuel-injection, and gaseous carburetor.

The converted vehicles performed similarly to the gasoline minivan. The University of Windsor's minivan had the lowest emissions, attaining ULEV levels $(0.035 \mathrm{~g} / \mathrm{mi}$ NMHC, $0.21 \mathrm{~g} / \mathrm{mi} \mathrm{CO}, 0.21 \mathrm{~g} / \mathrm{mi}$ NOx) with a gaseousinjected engine. Texas A\&M vehicle, which had a gaseousfuel injection system $(0.062 \mathrm{~g} / \mathrm{mi} \mathrm{NMHC}, 0.67 \mathrm{~g} / \mathrm{mi} \mathrm{CO}$, $0.27 \mathrm{~g} / \mathrm{mi} \mathrm{NOx}$ ) and the GMI Engineering and Management Institute's vehicle, which had a liquid-injection system $(0.097 \mathrm{~g} / \mathrm{mi}$ NMHC, $1.26 \mathrm{~g} / \mathrm{mi} \mathrm{CO}, 0.25 \mathrm{~g} / \mathrm{mi} \mathrm{NOx})$, both reached LEV levels.

Vehicles with an injection fuel system (liquid or gaseous) performed better in terms of emissions than a carbureted systems. Liquid injection appeared to be the best option for fuel metering and control for propane, but more research and calibration are necessary to improve the reliability and performance of this design.

\section{INTRODUCTION}

In June 1996, the U.S. Department of Energy (DOE), along with Natural Resources-Canada, and Chrysler Canada, sponsored a student competition involving propane as an alternative automotive fuel. The goal of this competition was to convert a 1996 gasoline-powered Chrysler minivan to dedicated propane operation with maximum production feasibility within certain parameters for vehicle performance. The converted vehicle had to have a minimum range of 400 $\mathrm{km}$, the same passenger and cargo space as the stock vehicle, and emissions and vehicle performance similar to that of the gasoline-powered vehicle (1) ${ }^{1}$. Also, schools had to perform the propane conversion according to American and Canadian safety codes for propane and propane-powered vehicles. The Challenge was hosted by the University of Windsor and Chrysler Canada in Windsor and Toronto, Canada.

Chrysler Canada donated 1996 Chrysler long-wheelbase minivans to each of the participating schools. They had a 3.3L V6 engine and 4-speed automatic transmission. The schools participating in this challenge were the University of Alberta, Texas Tech University, Texas A\&M University, École de technologie supérieure, University of Texas at El Paso, University of Texas at Austin, University of Oklahoma, Villanova University, Cedarville College, GMI Engineering and Management Institute, Western Washington University, and the Illinois Institute of Technology. The University of Windsor, the host school, participated in the competition and were scored but were not eligible for prizes due to their close working relationship with the Chrysler-Canada Engineering Centre. Of the 13 universities participating, 10 were able to undergo emissions testing.

As an automotive fuel, propane has an excellent potential to replace gasoline. Propane primarily consists of a simple hydrocarbon species, so it burns cleaner than gasoline (2). In a vehicle, propane is stored in liquid form in a pressurized system (at approximately $830 \mathrm{kPa}$ and ambient temperature), minimizing evaporative emissions and keeping a good energy content (by volume), if compared with other gaseous fuels.

\section{CONVERSION APPROACH}

Three fuel-delivery types were presented for this competition: gaseous carburetor, gaseous injection, and liquid injection. Although the fuel-delivery concept may have been

\footnotetext{
${ }^{1}$ Numbers in parentheses designate references at the end of the paper.
} 


\section{DISCLAIMER}

Portions of this document may be illegible in electronic image products. Images are produced from the best available original document. 
Table 1. Conversion Approach for the Schools Participating in the 1996 Propane Vehicle Challenge

\begin{tabular}{|c|c|c|c|c|}
\hline School & Fuel Management & Engine Controller & $\mathrm{CR}^{*}$ & Emissions Control \\
\hline Cedarville College & Gaseous Carburetor & $\begin{array}{l}\text { Autotronics Chrysler } \\
\text { Support II. ECO Fuel } \\
\text { Systems FSM controller }\end{array}$ & 9.2:1 & 3-part Propane Catalyst \\
\hline $\begin{array}{l}\text { Ecole } \\
\text { de technologie } \\
\text { superieure }\end{array}$ & $\begin{array}{l}\text { Evaporator } \\
\text { IMPCO }\end{array}$ & $\mathrm{N} / \mathrm{A}^{* *}$ & $\begin{array}{l}\text { Stock } \\
(8.9: 1)\end{array}$ & $\begin{array}{l}\text { Corning Electrically Heated } \\
\text { Catalyst }\end{array}$ \\
\hline $\begin{array}{l}\text { GMI Engineering } \\
\text { and Management }\end{array}$ & $\begin{array}{l}\text { Liquid Injection } \\
\text { BDE Ltd. Injectors }\end{array}$ & $\mathrm{OEM}$ & $11.0: 1$ & $\begin{array}{l}\text { Thermally Insulated Exhaust } \\
\text { System } \\
\text { 3-way Propane Catalyst }\end{array}$ \\
\hline $\begin{array}{l}\text { Illinois Institute of } \\
\text { Technology }\end{array}$ & $\begin{array}{l}\text { Vapor Injection } \\
\text { Siemens Automotive } \\
70 \text { psi/ } 50 \text { psi (for lean burn) }\end{array}$ & OEM & Stock & $\begin{array}{l}\text { Ozonator } \\
\text { Stock Catalyst }\end{array}$ \\
\hline $\begin{array}{l}\text { Texas A\&M } \\
\text { University }\end{array}$ & $\begin{array}{l}\text { Vapor Injection } \\
\text { Servojet Injectors (PN SP021) } \\
\text { @ } 40 \text { psia }\end{array}$ & $\begin{array}{l}\text { Mesa Environmental Gas } \\
\text { Engine-Management } \\
\text { System with OEM }\end{array}$ & $11.7: 1$ & $\begin{array}{l}\text { Electrically Heated 3-way } \\
\text { Catalyst and Main Catalytic } \\
\text { Converter (both Emitec } \\
\text { Gmbh) }\end{array}$ \\
\hline $\begin{array}{l}\text { Texas Tech. } \\
\text { University }\end{array}$ & $\begin{array}{l}\text { Vapor Injection } \\
\text { Bosch Injectors @80 psi }\end{array}$ & $\begin{array}{l}\text { Paxton Supercharger, } \\
\text { Motorola microprocessor } \\
\text { secondary controller }\end{array}$ & Stock & Increased Catalytic Volume \\
\hline $\begin{array}{l}\text { University of } \\
\text { Alberta }\end{array}$ & $\begin{array}{l}\text { Gaseous Carburetor } \\
\text { IMPCO EB1 vaporizer } \\
\text { IMPCO CA200 mixer } \\
\end{array}$ & $\begin{array}{l}\text { Autotronics } 5935 \\
\text { controller integrated with } \\
\text { OEM } \\
\end{array}$ & $10.5: 1$ & $\begin{array}{l}\text { Emitec Gmbh/ Englehard } \\
\text { Electrically Heated, Light off } \\
\text { and Main Catalysts }\end{array}$ \\
\hline $\begin{array}{l}\text { University of } \\
\text { Oklahoma }\end{array}$ & $\begin{array}{l}\text { Liquid Injection } \\
\text { Servojet SP021S1 Injectors }\end{array}$ & $\begin{array}{l}\text { Haltech E6A Electronic } \\
\text { Control Unit }\end{array}$ & Stock & Increased Catalyst Volume \\
\hline $\begin{array}{l}\text { University of } \\
\text { Texas, Austin }\end{array}$ & $\begin{array}{l}\text { Liquid Fuel Injection } \\
\text { Siemens DEKA II } 1604 \text { Injectors } \\
50 \text { psi and } 350 \text { psi (for hot starts) }\end{array}$ & $\begin{array}{l}\text { EFI Inc. Engine- } \\
\text { Management System }\end{array}$ & Stock & $\begin{array}{l}\text { Engelhard Close-Coupled And } \\
\text { Main LPG Catalysts }\end{array}$ \\
\hline $\begin{array}{l}\text { University of } \\
\text { Texas, El Paso }\end{array}$ & $\begin{array}{l}\text { Gaseous Carburetion } \\
\text { OHG X-450 mixer } \\
\text { OHG X-2 regulator } \\
\end{array}$ & $\begin{array}{l}\text { Autotronics } 5935 \\
\text { Controller Integrated with } \\
\text { OEM }\end{array}$ & Stock & $\begin{array}{l}\text { Cooled EGR } \\
\text { Allied Signal Propane- } \\
\text { Specific Catalyst }\end{array}$ \\
\hline $\begin{array}{l}\text { University of } \\
\text { Windsor }\end{array}$ & $\begin{array}{l}\text { Vapor Injection } \\
\text { Chrysler Injectors@45 psi }\end{array}$ & Chrysler CNG Controller & Stock & $\begin{array}{l}\text { Thermally Insulated Main } \\
\text { Catalytic Converter, } \\
\text { Electrically Heated Secondary } \\
\text { Converter }\end{array}$ \\
\hline $\begin{array}{l}\text { Villanova } \\
\text { University }\end{array}$ & $\begin{array}{l}\text { Liquid Injection } \\
\text { Siemens \#4612-402 Injectors } \\
75 \text { psi }\end{array}$ & $\begin{array}{l}\text { ACCEL Spark-Fuel } \\
\text { Management System with } \\
\text { OEM }\end{array}$ & Stock & Stock Catalyst \\
\hline $\begin{array}{l}\text { W. Washington } \\
\text { University }\end{array}$ & $\begin{array}{l}\text { Gaseous Carburetion } \\
\text { IMPCO carburetor } \\
\text { IMPCO regulator }\end{array}$ & $\begin{array}{l}\text { IMPCO Adaptive Digital } \\
\text { Processor }\end{array}$ & Stock & $\begin{array}{l}2 \text { CNG-Specific Catalysts } \\
\text { Chrysler California Catalyst }\end{array}$ \\
\hline
\end{tabular}

\footnotetext{
- Compression Ratio

** Not Available
} 
the same for some schools, the materials, components, and type of control made each conversion unique. Table 1 summarizes the conversion approaches of the participating schools.

Because of unavoidable delays with the delivery of the vehicles, schools had less that five months to complete the conversion. The biggest restriction in the conversion was the requirement to keep most of the OBD-II control (stock in the minivan) operational. Schools had to piggyback or override some of the OBD-II functions in order to include a new fuel controller.

\section{COMPETITION FUEL}

The fuel used for the emissions testing and during the competition met the Canadian standard CAN/CGSB-3.14M88, equivalent to GPA standard 2140-86 propane HD-5 fuel. An $\mathrm{H} / \mathrm{C}$ ratio of 2.2 and a specific calorific value of $46 \mathrm{MJ} / \mathrm{kg}$ were used when calculating exhaust emissions and fuel economy (2).

\section{TEST PROCEDURE}

Exhaust emissions tests were performed at Chrysler emissions facilities in Highland Park, MI. The 10 vehicles that were able to run on the chassis dynamometer were tested using the FTP cycle, immediately followed by a Highway Fuel Economy Test (HWFET) (3). Fuel Economy was calculated from the FTP (city fuel economy) and from the HWFET (highway fuel economy). All the vehicles were tested in one day, and three similar dynamometers (Clayton twin-rolls) were used. Vehicles were driven from Chrysler Canada facilities (Windsor, Ontario) to the emissions facilities in Highland Park the day before the emissions test took place. This drive is on highway- and city-type roads (approximate 30 $\mathrm{km}$ ), and it replaced the preconditioning schedule for the vehicles. Once in Highland Park vehicles were parked and soaked overnight. Table 2 summarizes the problems found with some of the vehicles during testing.

None of the problems encountered during the procedure were sufficient to abort any of the tests. Continuous gaseous emissions samples were taken from before the first (engine out) and after the last (tail pipe) catalyst present in the exhaust system (1).

Schools were required to include a k-type thermocouple before the catalyst in the exhaust system in order to measure the temperature of the exhaust gases coming into the catalyst. The output of the thermocouple was connected directly to a data acquisition system.
Table 2. Problems Encountered during Emissions Testing

\begin{tabular}{|l|l|}
\hline \multicolumn{1}{|c|}{ School } & \multicolumn{1}{|c|}{ Comments/Problems } \\
\hline Cedarville & $\begin{array}{l}\text { High engine and TP O2; possible vehicle engine \& TP } \\
\text { probe leak. Stall hill 1 accel. } \\
\text { Stall hill 2 accel; 26.5 s. D/M, 13 sec. test hold. } \\
\text { Exhaust system backfire. }\end{array}$ \\
\hline ETS & None \\
\hline GMI & None \\
\hline $\begin{array}{l}\text { Illinois Institute } \\
\text { of Technology }\end{array}$ & $\begin{array}{l}\text { High engine and TP O2; possible vehicle engine \& TP } \\
\text { probe leak. } \\
\text { Engine overheated during PCC of FEC, some loss of } \\
\text { engine coolant; 285 s. test hold. }\end{array}$ \\
\hline Texas A\&M & None \\
\hline $\begin{array}{l}\text { Texas Tecl. } \\
\text { University }\end{array}$ & $\begin{array}{l}\text { Difficult initial start, 1 stall, started when given half } \\
\text { throttle; } 2 \text { s. test hold. }\end{array}$ \\
\hline U. of Alberta & None \\
\hline $\begin{array}{l}\text { University of } \\
\text { Texas, El Paso }\end{array}$ & $\begin{array}{l}\text { Modification required on vehicle engine-out sample } \\
\text { probe prior to testing. } \\
\text { Rolls brake up at start of C-80, 2 stalls at initial start; } \\
30.3 \text { s. D/M hill 1. Difficult starting for phase 3 of c-80; } \\
25 \text { s. test hold. }\end{array}$ \\
\hline $\begin{array}{l}\text { Western } \\
\text { Washington U. }\end{array}$ & $\begin{array}{l}\text { High engine and TP O2; possible vehicle engine \& TP } \\
\text { probe leak }\end{array}$ \\
\hline U. of Windsor & \\
\hline
\end{tabular}

\section{EMISSIONS RESULTS}

Of the three schools that attempted to develop a liquidfuel-injection system for their vehicle, just one school had an operational vehicle at the time of emission testing. Although liquid injection was demonstrated to have the potential for better emissions and performance, it is also a more complicated system to calibrate and operate because injectors capable of handling liquid propane are not widely available and the possibility of nozzle tip freezing during the injection process under certain conditions.

Figure 1 summarizes the results for the three main pollutants (CO, NMHC, and NOx) during the FTP test. In the figure is also included results for the THC. The results were diverse; some vehicles had excellent emissions while others had high emissions. The University of Windsor's vehicle had the best overall emission performance, achieving levels comparable with those of California ULEV. Two vehicles (Texas A\&M University, and GMI) had emissions levels comparable with those of LEV. California levels for ULEV and LEV are given for Non-Methane Organic Gases (NMOG) measurements rather than the EPA's Non-Methane Hydrocarbons (NMHC) measurements, which were used in these results. An approximate conversion from NMHC to reactivity-adjusted NMOG for propane-powered vehicles is to multiply by 0.4 (4) making it possible for some of these vehicles to reach CARB-ULEV emissions levels. As expected, fuel-injection systems had lower emissions levels than did the more conventional carburetor systems. The best emission performance was from a gaseous injection system 
(University of Windsor), followed by a liquid injection system (GMI) and another gaseous injection system (Texas A\&M). The emissions of the best carburated vehicles were similar to TLEV levels, but fuel economy for these vehicles was slightly better than those for the injection systems. Table 4 (at the end of the paper) summarizes the emissions results for the emission test.

One more point to consider is that although $50 \mathrm{~K}-\mathrm{mi}$ emissions standards are used for comparison, no catalyst deterioration factors were used in the emissions results, and most of the schools equipped their vehicles with a new catalyst. The emissions results described in this paper are likely to be better than what would actually be achieved at 50K-mi. The catalyst efficiencies are summarized in Table 5 (at the end of the paper). The efficiency of the catalyst was calculated by dividing the amount of the pollutant measured from the engine out side $(\mathrm{g} / \mathrm{mi})$ by the amount measured from the tail pipe $(\mathrm{g} / \mathrm{mi})$, then subtracting from 1 . The low emissions were reached, in part, because the high catalyst efficiencies. Further demonstrating this phenomenon is the fact that the vehicle with the lowest emissions also showed high catalyst efficiencies. As expected, the pollutant best controlled by the catalyst was CO, followed by THC. NOx was, on average, moderately controlled by the catalysts, with an average efficiency of only a $63 \%$. However, the three top emissions schools had a heated or thermal insulated catalyst and a catalyst efficiency for NOx of over $85 \%$.

Figure 1. 1996 PVC Emissions Results

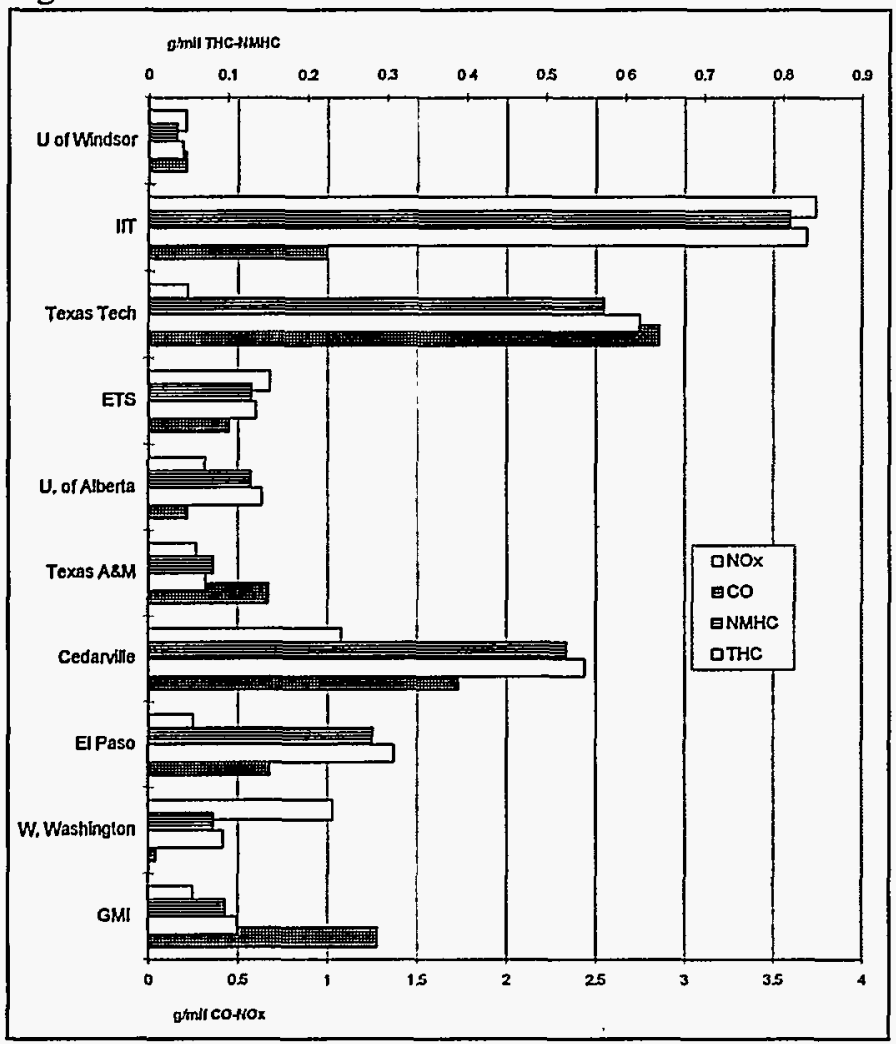

Although, the vehicle having the lowest emissions (U. of Windsor) did not increase the compression ratio (CR) in their vehicle, three of the four vehicles with an increased $C R$ were in the top five emissions performance. The University of Alberta with a carburetor system and a CR of 10.5:1 achieved emissions levels comparable to TLEV.

The difference in performance between electrical heated or thermally insulated catalysts and catalysts without any type of heat assistance was significant. To show the effectiveness of the heated catalyst, we can compare two of the vehicles: Texas A\&M and Cedarville College. Figure 2 and 3 shows the temperature of the exhaust gases (y-axis) Vs time ( $x$-axis) for the first $600 \mathrm{~s}$. of the FTP test. In both cases, the exhaust gas temperature reached normal operation temperature (around $900^{\circ} \mathrm{F}$ ) in $230 \mathrm{~s}$., but the conversion efficiencies for Texas A\&M (87\%) for the first phase (505 s.) are far superior to those from Cedarville $(60 \%$, see Table 4$)$. For the second phase (stabilized phase), the catalyst efficiencies are similar for both schools, except for the NOx values.

Figure 2. Exhaust Gas Temperature for Cedarville College's Vehicle

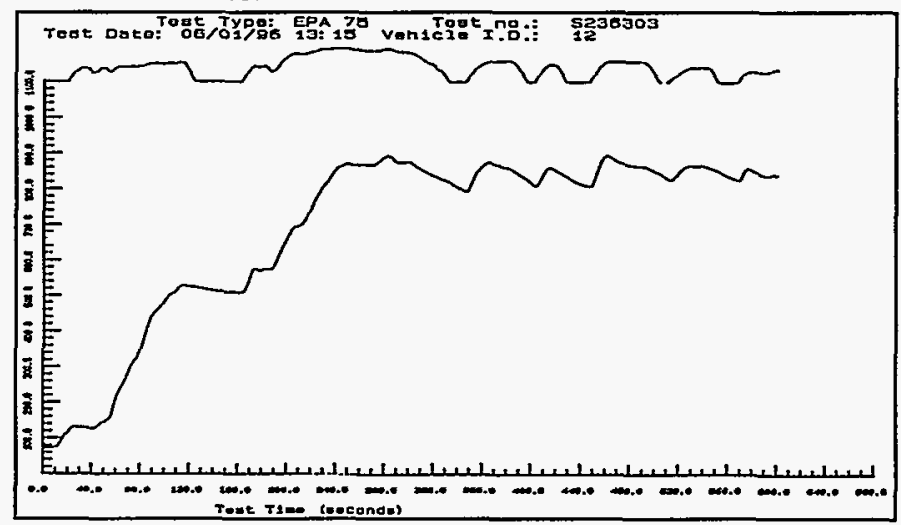

Figure 3. Exhaust Gas Temperature for Texas A\&M's vehicle

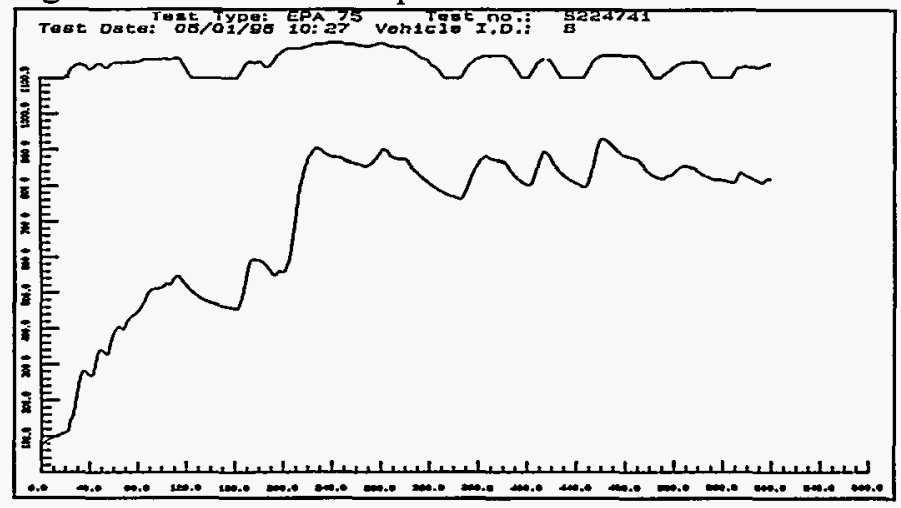

Another factor contributing to the wide range of results was the ability of the controller to keep the air-fuel ratio $(A / F)$ of the mixture within the optimum range (stoichiometric). This case is demonstrated when we compared IIT and Windsor A/F control. Both schools chose the gaseous fuel-injection system, but the Windsor system was more successful in keeping the mixture in the right range (see Figures 4 and 5). For the 
University of Windsor, small and more frequent oscillation indicates faster response of the engine control system (5). This control behavior was also found in the vehicles from GMI, Texas A\&M, and Alberta.

Figure 4. A/F for Windsor Vehicle during FTP Emission Test

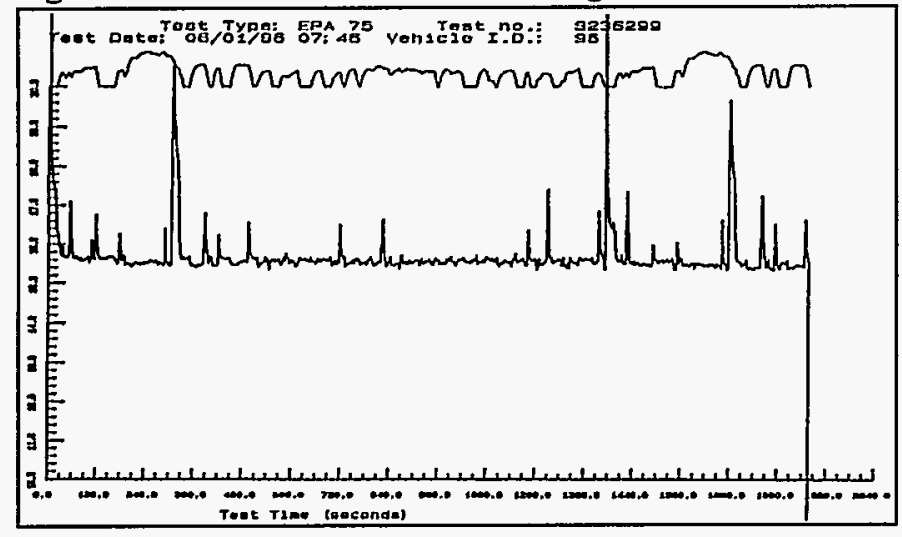

Figure 5. A/F for IIT Vehicle during FTP Emission Test

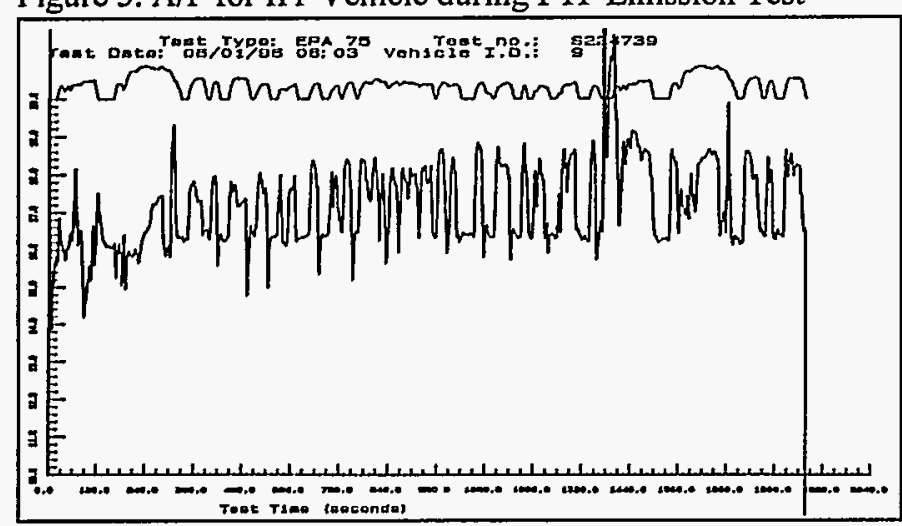

FUEL ECONOMY

Table 3 shows the fuel economy of the vehicles participating in the 1996 Propane Vehicle Challenge. These results are given in $\mathrm{km} / \mathrm{L}$ of propane. In an energy densitybasis, one liter of gasoline is equivalent to 1.3 liters of propane. The results are as good or better than the fuel economy listed for the gasoline minivan of $7.74 \mathrm{~km} / \mathrm{L}(18$ $\mathrm{mpg}$ ) city and $10.32 \mathrm{~km} / \mathrm{L}(24 \mathrm{mpg})$ highway (6). On a gasoline-equivalent basis, the U. of Alberta's vehicle would achieve $7.80 \mathrm{~km} / \mathrm{L}$ city and $13 \mathrm{~km} / \mathrm{L}$ highway.

The vehicles with the best fuel economy were not the same as those with the best emissions test results. Of the top 4 schools in terms of fuel economy (city and highway), three used a carburetor system and one used gaseous injection. These results may suggest that carburetor systems may have been operating lean during some operating conditions of the engine. The top four schools achieved the best fuel economy results over both the city and the highway cycles.
Table 3. 1996 PVC: Fuel Economy Results

\begin{tabular}{|l|c|c|}
\cline { 2 - 3 } \multicolumn{1}{c|}{} & City $(\mathrm{km} / \mathrm{L})$ & Hway $(\mathrm{km} / \mathrm{L})$ \\
\hline GMI & 5.59 & 8.81 \\
\hline W. Washington & 5.63 & 8.51 \\
\hline UTEP & 5.85 & 9.29 \\
\hline Cedarville & 5.25 & 8.99 \\
\hline Texas A\&M & 5.63 & 9.03 \\
\hline U. of Alberta & 5.93 & 9.80 \\
\hline ETS & 5.80 & 9.24 \\
\hline Texas Tech & 5.42 & 8.60 \\
\hline IIT & 5.98 & 9.37 \\
\hline U of Windsor & 5.29 & 8.21 \\
\hline
\end{tabular}

\section{CONCLUSIONS}

1. A closed-loop fuel injection-system was shown to be the best configuration for exhaust emissions control for a production vehicle converted to dedicated propane operation. Most of the conversions did not take advantage of the higher octane number of propane; just a few schools had time to do internal engine modifications that could yield better performance.

2. Liquid fuel injection of propane is feasible, but it needs further more development to be production ready. The lack of a propane fuel pump to keep the propane in the liquid state in the fuel system is one of the main reasons for many of the schools opting for a gaseous fuel injection system.

3. Carburetor systems for propane yielded fair emissions and better than average fuel economy. These systems have been on the market for a many years and have been found reliable. However, they can not control the air/fuel ratio as precisely nor respond as quickly as fuel injection systems.

4. As a light-duty-vehicle fuel, propane has the potential to achieve ULEV exhaust emission levels

\section{REFERENCES}

1. "1996 Propane Vehicle Challenge: Rules and Regulations," Argonne National Laboratory, 1995.

2. "Alternatives to Traditional Transportation Fuels: An Overview," DOE/ELA-08585/O, June 1994.

3. Code of Federal Regulations, Title 40, Part 86.

4. Newkirk, M.S., Smith, L.R., Payne, M.E., Segall, J.S., "Reactivity and Exhaust Emissions from an EHCEquipped LPG-Conversion Vehicle Operating on Butane/Propane Fuel Blends," SAE Paper 961991, 1996.

5. Matthews, R.D., Chiu, J., Zheng, J., Wu, D.-Y., Dardalis, D., Shen, K., Roberts, C., Hall, M.J., Ellzey, J.L., Mock, C., Wicker, R.B., Jaeger, S., "The Texas Project: Part 1Emissions and Fuel Economy of Aftermarket CNG and LPG Conversions of Light-Duty Vehicles," SAE Paper 962038, 1996.

6. 1996 EPA Fuel Economy Guide. 